\title{
The Effect of Ordinary Portland Cement Substitution on the Thermal Stability of Geopolymer Concrete
}

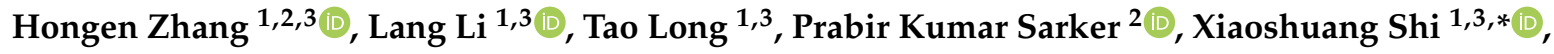 \\ Gaochuang Cai ${ }^{4}$ and Qingyuan Wang ${ }^{1,3,5, *}$ \\ 1 Key Laboratory of Deep Underground Science and Engineering (Ministry of Education), \\ School of Architecture and Environment, Sichuan University, Chengdu 610065, China \\ 2 Department of Civil Engineering, Curtin University, GPO Box U1987, Perth, WA 6845, Australia \\ 3 Failure Mechanics and Engineering Disaster Prevention and Mitigation Key Laboratory of Sichuan Province, \\ Sichuan University, Chengdu 610207, China \\ 4 Laboratoire de Tribologie et de Dynamique des Systèmes (LTDS), Ecole Nationale d'Ingénieurs de \\ Saint-Etienne (ENISE), University de Lyon, UMR 5513, 58 Rue Jean Parot, 42023 Saint-Etienne, France \\ 5 School of Mechanical Engineering, Chengdu University, Chengdu 610106, China \\ * Correspondence: shixs@scu.edu.cn (X.S.); wangqy@scu.edu.cn (Q.W.)
}

Received: 25 June 2019; Accepted: 3 August 2019; Published: 7 August 2019

\begin{abstract}
The influence of using cement on the residual properties of fly ash geopolymer concrete (FAGC) after exposure to high temperature of up to $800^{\circ} \mathrm{C}$ was studied in terms of mass loss, residual compressive strength and microstructure. The mass loss was found to increase with the increase of exposure temperature, which is attributed to vaporization of water and dehydroxylation of sodium aluminosilicate hydrate (N-A-S-H) gels. The dehydroxylation of calcium silicate hydrate (C-S-H) gels and the disintegration of portlandite were responsible for higher mass loss ratio of FAGCs containing cement. The results showed that cement could increase compressive strength of FAGCs up to $200{ }^{\circ} \mathrm{C}$, after which a significant reduction in residual strength was observed. It was found that FAGCs without cement yielded higher residual strength than the original strength after heating up to $600{ }^{\circ} \mathrm{C}$. The observed increase of compressive strength up to $200{ }^{\circ} \mathrm{C}$ was attributed to the secondary geopolymerization which was evidenced in the scanning electronic microscopy (SEM) images.
\end{abstract}

Keywords: elevated temperatures; residual compressive strength; mass loss ratio; geopolymer concrete; secondary geopolymerization

\section{Introduction}

The continuous increasing demand of cement and the associated emission of a large quantity of carbon dioxide is a major sustainability issue for cement industry. Hence, geopolymer was created by researchers as an alternative low-emission binder to cement in concrete industry [1]. Geopolymer is an inorganic polymer produced by alkaline activation of raw materials that are affluent in silicates and aluminate [2] and geopolymer plays the binder part in geopolymer concrete. The typical raw materials used for the manufacturing of geopolymer concrete include fly ash, metakaolin and slag [3-5]. Since geopolymer concrete uses industrial by-products instead of energy-intensive cement, its use in construction can help improve the sustainability features of concrete industry.

Fly ash-based geopolymer concrete (FAGC) can be regarded as an emerging low-emission concrete which is made using fly ash-based geopolymer binder. In recent years, FAGC has been drawing more and more attention because of its excellent mechanical performance as well as good durability $[6,7]$. However, low calcium fly ash based geopolymers usually needs heat curing to accelerate setting and hardening [8], which limits its practical engineering application. Therefore, attempts have been made 
to produce FAGC with required properties by curing at ambient temperature [9-11]. It is well-known that Portland cement-based concrete develops the strength required for in-situ construction at room temperature because the hydration reaction of cement occurs at ambient temperature. Thus, several researchers succeeded to utilize a small percentage of Portland cement to improve mechanical properties and microstructure of FAGC at room temperature [12-14]. Nath and Sarker [12] proposed that the inclusion of an appropriate proportion of ordinary Portland cement (OPC) could promote the geopolymerization process and help geopolymer concretes obtain acceptable workability and desirable strength.

Since exposure to extreme temperatures and accidental fire have detrimental effects on properties of concrete, it is essential to evaluate the residual strength of geopolymer concrete after being exposure to elevated temperatures. This knowledge is important for assessment of the performance of concrete structures after an event of accidental fire. As a newly developing concrete, much more researches are needed to understand the effect of elevated temperature on properties of FAGC. Several past works [15-18] reported the performance of FAGCs after exposure to elevated temperatures and the results were impressive. Abdulkareem et al. [16] investigated physical and mechanical behavior of fly ash geopolymeric composites after elevated temperature exposure. The tested results showed that geopolymeric composites experienced strength at elevated temperatures. They stated that the deterioration of geopolymers was caused by the expansion of residual silicate phase. Sarker et al. [15] analyzed spalling behavior and mechanical performance of fly ash geopolymer concrete after exposure to simulated fire. They stated that geopolymer concrete presented considerably better residual properties than OPC concrete after exposure to fire. However, those works focused mainly on heat-cured specimens and only few studies were found on ambient-cured specimens, especially the ambient-cured specimens containing cement. It is important to study the behavior of ambient-cured specimens containing cement at elevated temperature because this experience will provide theoretical supports for engineering applications. Therefore, this study aimed at investigating the effect of cement on the thermal stability properties of ambient-cured FAGCs after exposure to elevated temperatures.

\section{Materials and Methods}

\subsection{Materials}

The fine and coarse aggregates were river sand and crushed rock, respectively. The maximum size of fine and coarse aggregate were $4 \mathrm{~mm}$ and $22 \mathrm{~mm}$, respectively. The packing densities of fine and coarse aggregate were $1342 \mathrm{~kg} / \mathrm{m}^{3}$ and $1479 \mathrm{~kg} / \mathrm{m}^{3}$. The apparent densities of fine and coarse aggregate were $2381 \mathrm{~kg} / \mathrm{m}^{3}$ and $2632 \mathrm{~kg} / \mathrm{m}^{3}$. Figure 1 shows the particle size distribution of coarse aggregate.

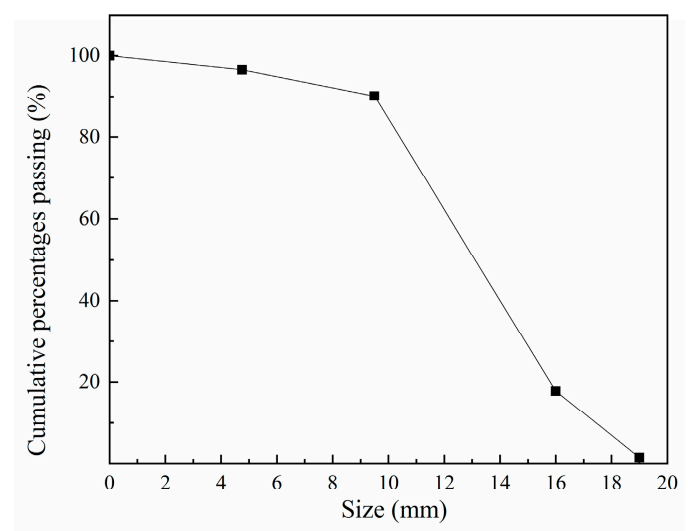

Figure 1. The particle size distribution of coarse aggregate.

The sodium hydroxide (NaOH, Chengdu Kelong Chemical Reagent Factory, Chengdu, China) solution of $10 \mathrm{M}$ was prepared by mixing $\mathrm{NaOH}$ particles of $96 \%$ purity with distilled water 
approximately $24 \mathrm{~h}$ prior to mixing FAGC. The alkaline solution was prepared by mixing sodium silicate $\left(\mathrm{Na}_{2} \mathrm{SiO}_{3}\right.$, Foshan Zhongfa Silicate CO.LTD, Foshan, China) solution and $\mathrm{NaOH}$ solution at a mass ratio of 2.5:1. The chemical compositions of $\mathrm{Na}_{2} \mathrm{SiO}_{3}$ solution were $\mathrm{Na}_{2} \mathrm{O}=15.4 \%, \mathrm{SiO}_{2}=38.5 \%$ and $\mathrm{H}_{2} \mathrm{O}=46.1 \%$ by mass and the modulus ratio $(M s)$ was 2.5 .

Commercially available low-calcium fly ash (ASTM C618 Class F [19], Shenzhen Dot Technology Co., Ltd, Shenzhen, China) was used as the main binder material in geopolymer concrete. It can be seen from Figure $2 \mathrm{a}$ that the fly ash particles are of spherical shape. The Chinese $42.5 \mathrm{R}$ ordinary Portland cement (Sichuan Lanfeng Cement Co.,Ltd, Chengdu, China) conforming with the requirements of the national industry standard "GB 175-2007/XG1-2009" [20] was used in this study. The cement particles are of irregular shape (Figure $2 \mathrm{~b}$ ). The chemical compositions determined using $\mathrm{X}$-ray fluorescence (XRF, XRF-1800, SHIMADZU, Kyoto, Japan) and loss on ignition (LOI) of fly ash and cement were presented in Table 1. Additionally, the mineral compositions of OPC are illustrated in Table 2.

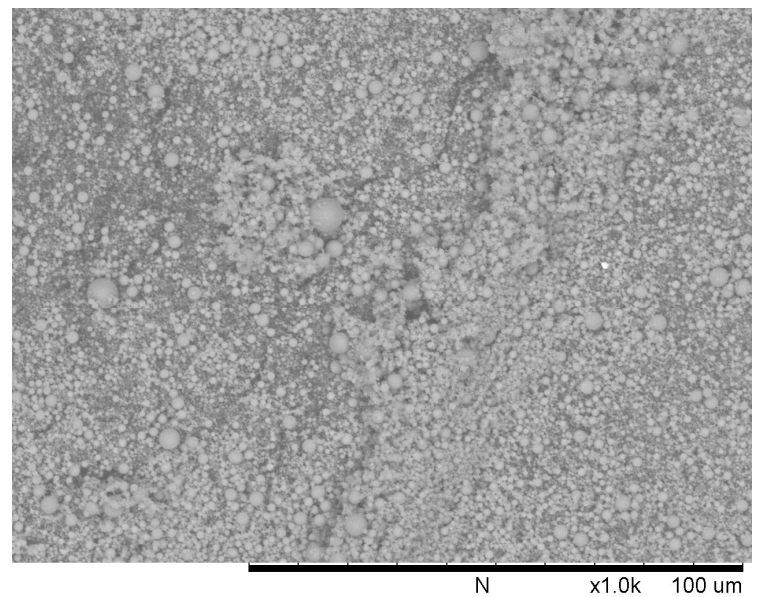

(a)

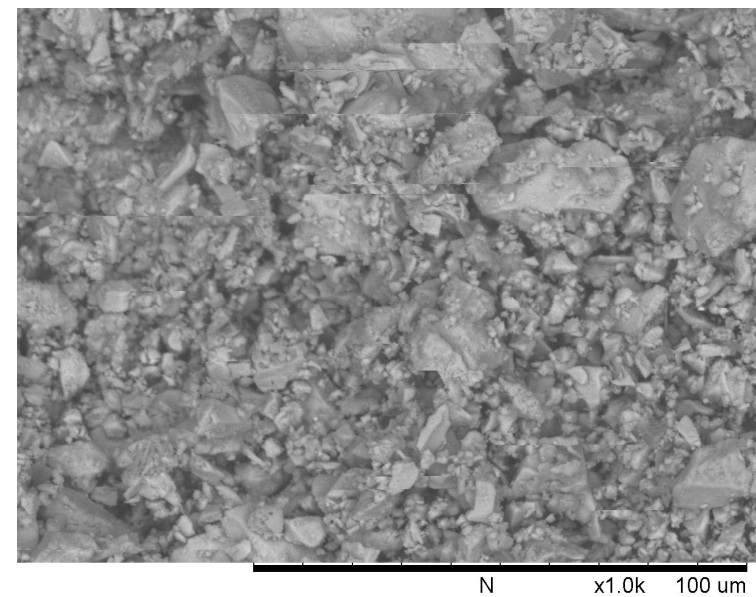

(b)

Figure 2. Scanning electron micrographs of: (a) fly ash; (b) cement.

Table 1. Chemical composition of fly ash and cement.

\begin{tabular}{ccccccccccc}
\hline $\begin{array}{c}\text { Chemical } \\
\text { Composition }\end{array}$ & $\mathrm{SiO}_{2}$ & $\mathrm{Al}_{2} \mathrm{O}_{3}$ & $\mathrm{CaO}$ & $\mathrm{Fe}_{2} \mathrm{O}_{3}$ & $\mathbf{M g O}$ & $\mathbf{K}_{2} \mathrm{O}$ & $\mathrm{SO}_{3}$ & $\mathrm{TiO}_{2}$ & $\mathrm{Na}_{2} \mathrm{O}$ & $\mathrm{LOI}^{+}$ \\
\hline Fly Ash (\%) & 49.05 & 26.40 & 5.2 & 4.64 & 3.72 & 4.85 & 2.00 & 1.16 & 0.8 & 2.83 \\
Cement (\%) & 17.78 & 2.49 & 63.67 & 2.5 & 3.09 & 0.46 & 4.77 & 0.80 & 0 & 4.53 \\
\hline \multicolumn{8}{c}{ Loss on ignition. }
\end{tabular}

Table 2. The mineral compositions of cement.

\begin{tabular}{cccccc}
\hline Mineral Composition & $\mathrm{Ca}_{3} \mathrm{SiO}_{\mathbf{5}}$ & $\mathrm{Ca}_{\mathbf{2}} \mathrm{SiO}_{\mathbf{4}}$ & $\mathrm{Ca}_{\mathbf{2}} \mathrm{Fe}_{\mathbf{1 . 4 0}} \mathrm{Al}_{\mathbf{0 . 6 0}} \mathrm{O}_{\mathbf{5}}$ & $\mathrm{CaSO}_{\mathbf{4}}$ & $\mathrm{CaCO}_{\mathbf{3}}$ \\
\hline SemiQuant (\%) & 44.55 & 38.61 & 3.98 & 6.92 & 5.94 \\
\hline
\end{tabular}

\subsection{Specimen Preparation}

Three series of concrete were prepared to carry out the relevant investigation. The concrete mixture proportions are given in Table 3 and the used cement contents were $0 \%, 5 \%$, and $10 \%$ by weight of the total binder (cement and fly ash). 
Table 3. Mixture design of the FAGC.

\begin{tabular}{cccccc}
\hline \multicolumn{6}{c}{ Mixture Design of the FAGC $\left(\mathbf{k g} / \mathbf{m}^{\mathbf{3}}\right)$} \\
\hline Mixes & Coarse Aggregate & Sand & Fly Ash & OPC & Alkaline Solution \\
\hline OPC-0 & 1172 & 539 & 459 & 0 & 200 \\
OPC-5 & 1172 & 539 & 436.05 & 22.95 & 200 \\
OPC-10 & 1172 & 539 & 413.10 & 45.9 & 200 \\
\hline
\end{tabular}

The concrete mixtures were mixed using a laboratory pan mixer. The aggregates and binders were first mixed for about $2 \mathrm{~min}$. The alkaline solution was then gradually added and the mixing was continued for about $3 \mathrm{~min}$ to obtain a consistent mixture. The fresh concrete was cast in 100-mm cube moulds in two layers on a vibration table. Subsequently, the specimens were covered by a plastic film and cured in a controlled condition at $20^{\circ} \mathrm{C}$ and $65 \%$ relative humidity for $24 \mathrm{~h}$. The specimens were then removed from the moulds and stored in a controlled condition at $20^{\circ} \mathrm{C}$ in accordance with "GB/T 50081-2002" [21] until the testing age.

\subsection{Heating Details}

A number of samples were exposed to five different temperatures, namely 100, 200, 400, 600 and $800{ }^{\circ} \mathrm{C}$ after curing for 90 days in room temperature. In stage I, the furnace temperature was increased from room temperature to the target temperature at a heating rate of $2{ }^{\circ} \mathrm{C} / \mathrm{min}$. In stage II, the target temperature was maintained for. In stage III, the furnace was turned off to allow the specimens to cool down to ambient temperature naturally. The heating regimes used in this study are presented in Figure 3.

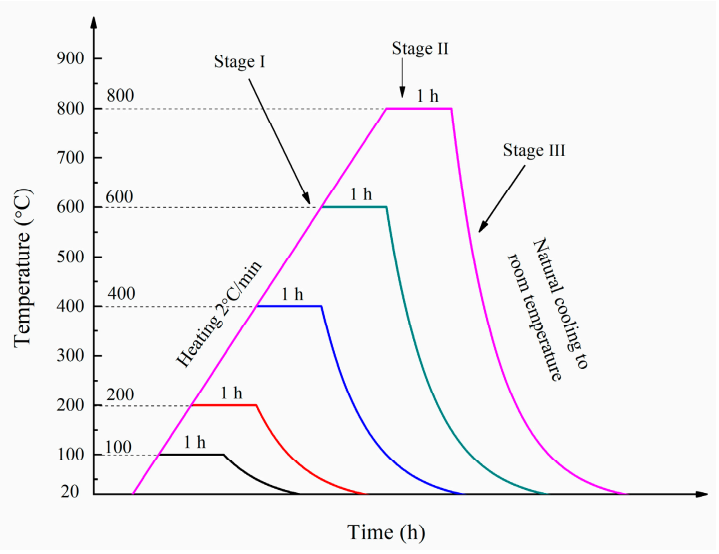

Figure 3. The heating regime.

\subsection{Determination of Mass Loss by High Temperature Exposure}

All samples exposed to each target temperature were also used for determination of the mass loss ratio of FAGC by Equation (1). The average mass loss ratio was found from three identical specimens.

$$
R=\frac{M_{b}-M_{a}}{M_{b}} \times 100 \%
$$

where is the percentage of mass loss, $M_{b}$ and $M_{a}$ are the mass of sample before and after exposure to the target temperature.

\subsection{Compressive Strength Test}

A $2000 \mathrm{kN}$ electro-hydraulic mechanical testing machine was used to obtain the compressive strength of concrete specimens. The initial and residual compressive strength of FAGC samples were 
obtained with a loading rate at $0.5 \mathrm{MPa} / \mathrm{s}$ according to GB/T50081-2002 [21]. This test procedure was used to evaluate the residual compressive strength value of FAGC after exposure to elevated temperature. The strength of three samples was obtained to determine the average compressive strength values according to GB/T50081-2002 [21].

\subsection{Scanning Electron Microscopic Images}

Scanning electron microscopy (SEM) was conducted with TM3000 (HITACHI, Kyoto, Japan) instrument to investigate the microstructural deterioration of the FAGC samples because of exposure to elevated temperatures. The fragment of sample without coarse aggregate was selected to perform SEM.

\subsection{Thermogravimetric Analysis (TGA)}

The aggregates were weeded out when preparing the samples for the thermogravimetric analysis (TGA) test. Fragments of FAGC specimens unexposed to elevated temperatures were powdered to conduct the TGA test through METTLER TOLEDO TGA/DSC2/1600 (METTLER TOLEDO, Zurich, Switzerland) instrument in alumina crucibles in the nitrogen environment $\left(\mathrm{N}_{2}\right.$ flowing at $\left.50 \mathrm{~mL} / \mathrm{min}\right)$, and then elevated to about $800^{\circ} \mathrm{C}$ with a constant heating rate of $10^{\circ} \mathrm{C} / \mathrm{min}$ in the same gas environment. One sample for each group was prepared to conduct the TGA test.

\section{Results and Discussions}

\subsection{Mass Change by High Temperature Exposure}

The percentage of mass loss after exposure to elevated temperatures were presented in Figure 4. It can be seen from Figure 4 that the percentage of mass loss increased with the increases of temperature and the cement content. It is observed from Figure 4 that the rate of mass change slowed down after $200{ }^{\circ} \mathrm{C}$, indicating that the mass loss mainly occurred before $200{ }^{\circ} \mathrm{C}$. The mass loss occurred within this temperature range accounted for more than $50 \%$ of the total mass loss.

The thermogravimetric analysis (TGA) and derivative thermogravimetry (DTG) of geopolymer concrete are presented in Figures 5 and 6, respectively. It can be observed in Figure 5 that the first mass loss peak of OPC- 0 occurred at about $48^{\circ} \mathrm{C}$ and those of OPC- 5 and OPC-10 occurred at about $57^{\circ} \mathrm{C}$, which was believed to be the evaporation of free water existing in concrete. Therefore, the mass loss occurred before $100{ }^{\circ} \mathrm{C}$ is attributed to the loss of free water. The second peak of OPC-0 occurred at about $97^{\circ} \mathrm{C}$ and those of OPC-5 and OPC-10 occurred at $107^{\circ} \mathrm{C}$ in Figure 5 could be attributed to the loss of chemically combined water in the N-A-S-H gel [22-24] and portlandite, C-S-H and ettringite $[25,26]$, which could be responsible for the mass loss occurred between $100{ }^{\circ} \mathrm{C}$ and $200{ }^{\circ} \mathrm{C}$. The inclusion of OPC increased the calcium content, resulting in an increase in portlandite, $\mathrm{C}-\mathrm{S}-\mathrm{H}$ and ettringite in the FAGC samples. Therefore, the percentage of mass loss increased with the OPC content. The heat curing method could accelerate the rate of geopolymerization and improve the amounts of reaction products. Since the cement hydration process is an exothermic action [27], the cement hydration heat could promote the geopolymerization and increase the quantity of N-A-S-H gel. This could be regarded as another reason to explain why the percentage of mass loss increased with the increase of OPC content.

The mass loss between 200 and $400{ }^{\circ} \mathrm{C}$ is attributed to continuous dehydroxylation of N-A-S-H gel [28] and C-S-H [25,29]. This is consistent with the information presented in Figure 5 that the mass loss rate of OPC- 0 was constant between $200{ }^{\circ} \mathrm{C}$ to $400{ }^{\circ} \mathrm{C}$. At the same time, the loss of interlayer water in pores of N-A-S-H as well as to the first stage of dehydroxylation makes contributions to the mass loss occurred within this temperature range. It is similar to the explanation proposed by several authors [30-32] when they investigated cement-based concrete. Additionally, the mass loss of OPC-5 and OPC-10 occurred within this temperature range is also resulted from the dehydration of C-S-H. As can be seen from the DTG curve of OPC-0 (Figure 6), the mass loss occurred in the range of about $585^{\circ} \mathrm{C}$ to $695^{\circ} \mathrm{C}$ is associated with the dehydroxylation of $\mathrm{OH}$ groups, such as sodium-based 
geopolymers. But the dehydroxylation of $\mathrm{OH}$ groups made a very little contribution to the mass loss of OPC-5 and OPC-10 samples within this temperature range. The mass loss of OPC-5 and OPC-10 was mainly induced by the decomposition of $\mathrm{Ca}(\mathrm{OH})_{2}$ in this temperature range. The DTG diagram implied that much more $\mathrm{Ca}(\mathrm{OH})_{2}$ was produced in FAGC containing $10 \%$ cement. Finally, the mass loss rate stabilized again after $695^{\circ} \mathrm{C}$, which can be seen from Figure 6.

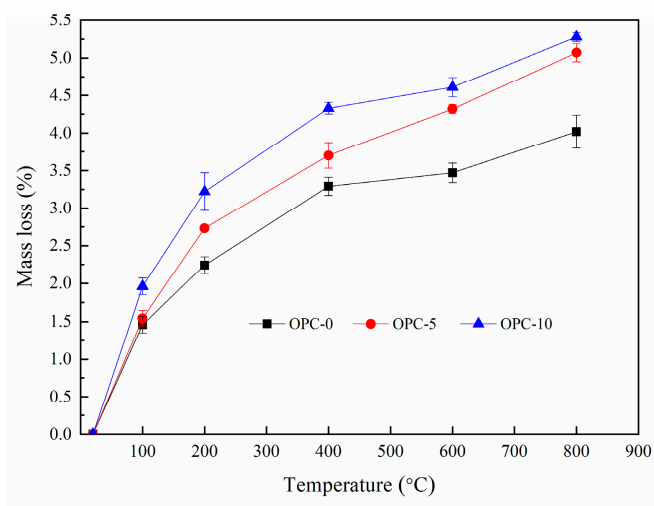

Figure 4. The percentage of mass loss at elevated temperatures.

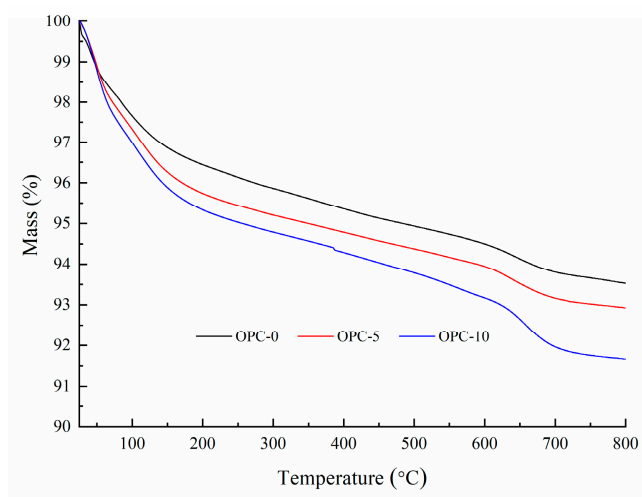

Figure 5. The TGA curves of low-calcium FAGC samples.

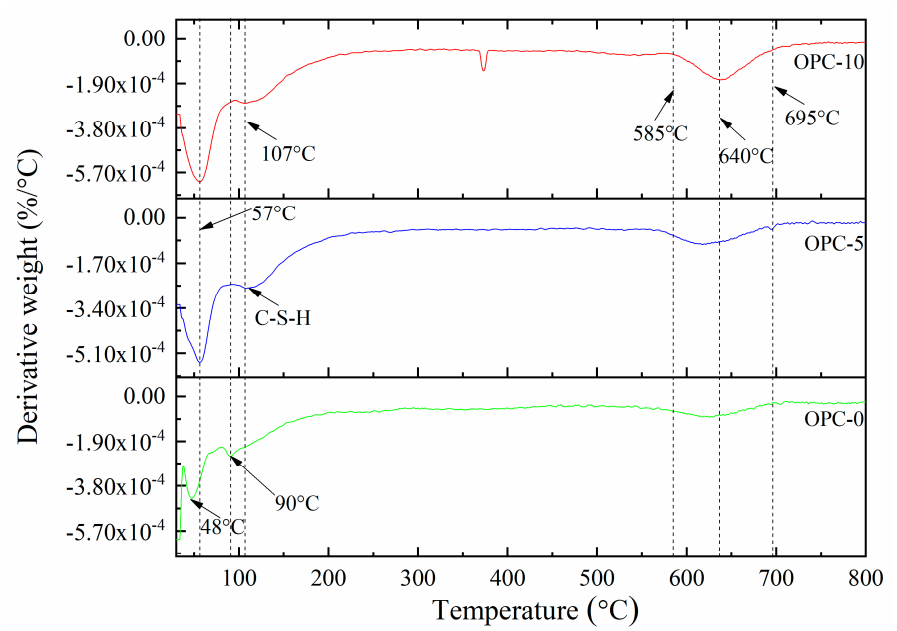

Figure 6. The DTG curves of low-calcium FAGC samples.

\subsection{Compressive Strength after Exposure to Elevated Temperatures}

The compressive strengths of FAGC before and after exposure to target temperatures are illustrated in Figure 7. It can be seen from Figure 7 that the compressive strength of FAGCs without cement increased up to $200{ }^{\circ} \mathrm{C}$ and declined during the temperature range of $200-800{ }^{\circ} \mathrm{C}$. The trend of this 
change is consistent with that of heat-cured geopolymer concrete samples [28,33]. The improvement in compressive strength up to $200{ }^{\circ} \mathrm{C}$ resulted from the secondary geopolymerization occurring during the heating process, which was one hypothesis promoted by other authors [34]. In general, FAGC should be cured at the temperature ranging from $50^{\circ} \mathrm{C}$ to higher temperature to achieve more complete geopolymerization. In view of this fact, some fly ash particles and silicate phases would be left unreacted if geopolymer concrete was cured at room temperature. Therefore, the results could provide a strong experimental support for the above hypothesis. Türkmen et al. [35] also believed that the beneficial effect of thermal drying was helpful for the increase of compressive strength until $200{ }^{\circ} \mathrm{C}$. $\mathrm{Up}$ to $200^{\circ} \mathrm{C}$, the enhancement in compressive strength of FAGCs containing cement also resulted from the following two primary reasons. Firstly, the product of cement hydration reaction could improve compressive strength. Secondly, the filler effect of any unreacted cement particles that filled the interstitial spaces existing in the concrete structure resulted in the enhancement of compressive strength [33].

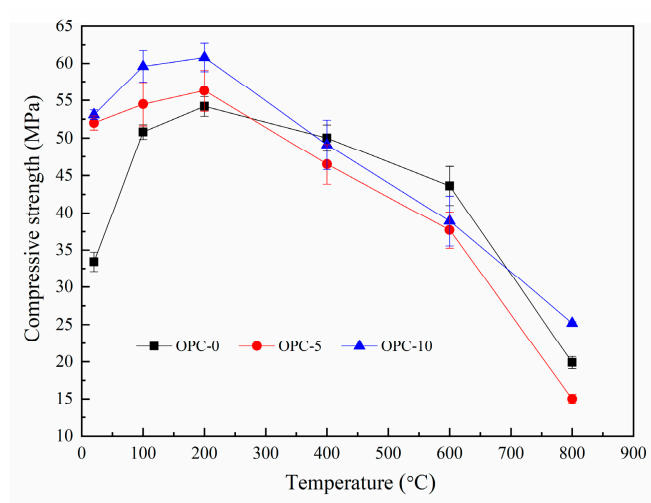

Figure 7. Residual compressive strength of low-calcium FAGC.

The significant decrease of compressive strength was largely associated with the following reasons. Firstly, the compressive strength reduction was related to the evaporation of chemically combined water, which could be observed from Figure 6. This is because that this typical water plays as an indispensable part of the structure of geopolymer gels. In addition, there was a mass loss rate peak between 585 and $695{ }^{\circ} \mathrm{C}$ (Figure 6), indicating the dehydroxylation of N-A-S-H gel and other hydrates (C-S-H and ettringite) gel, which was also responsible for the reduction of compressive strength. Being exposure to $800^{\circ} \mathrm{C}$ brought about a dramatic decline in compressive strength for all groups, which can be mainly ascribed to the serious microstructural deterioration including large cracks produced by excessive vapor pressure and the difference in thermal strain of geopolymer and aggregates. The strength loss caused by the microstructural deterioration is further discussed in Section 3.3. Additionally, the cement hydration product dehydrated at this temperature and led to a decline in compressive strength [35].

The change trend of compressive strength of FAGC at each target temperature can also be obtained from Figure 7. It was easy to find that the improvement in compressive strength mainly occurred at $100{ }^{\circ} \mathrm{C}$ and the loss of compressive strength largely took place at $800^{\circ} \mathrm{C}$. At $100{ }^{\circ} \mathrm{C}$, the percentage of compressive strength enhancement of OPC-0 was about $52.1 \%$, which was much higher than that of OPC-5 (4.8\%) and OPC-10 (12.2\%), indicating that secondary geopolymerization made more contributions to the compressive strength improvement of OPC-0 samples. Research [36] reported that water played a vital part in providing the essential liquid environment for dissolution of fly ash particles, hydrolysis and condensation reactions as geopolymerization process continues which could be obtained by Equations (2) and (3) [37]. There was much more free water in the geopolymer concrete without cement than specimens containing cement. It was because that some free water was consumed by the cement hydration in specimens containing cement. Consequently, the process of the destruction of fly ash particles and hydrolysis of existing $\mathrm{Al}^{3+}$ and $\mathrm{Si}^{4+}$ happened in the FAGCs without cement during geopolymer synthesis (referring to Equation (2)) was promoted [36], which led to relatively 
much more complete secondary geopolymerization up to $100{ }^{\circ} \mathrm{C}$. Therefore, geopolymer concrete without cement experienced much more significant secondary geopolymerization, resulting in greater improvement of compressive strength. At $800{ }^{\circ} \mathrm{C}$, the reduction in compressive strength of OPC- 0 , OPC- 5 and OPC- 10 were $54.4 \%, 60.2 \%$ and $35.2 \%$ respectively, indicating OPC-5 samples experienced the most severe compressive strength deterioration.

$$
\begin{aligned}
& \left(\mathrm{Si}_{2} \mathrm{O}_{5}, \mathrm{Al}_{2} \mathrm{O}_{2}\right)_{\mathrm{n}}+\mathrm{nSiO}_{2}+4 \mathrm{nH}_{2} \mathrm{O}+\mathrm{nOH}^{-} \rightarrow \mathrm{n}(\mathrm{OH})_{3}-\mathrm{Si}-\mathrm{O}-\underset{(\mathrm{OH})_{2}}{\mathrm{Al}^{-}}-\mathrm{O}-\mathrm{Si}-(\mathrm{OH})_{3}
\end{aligned}
$$

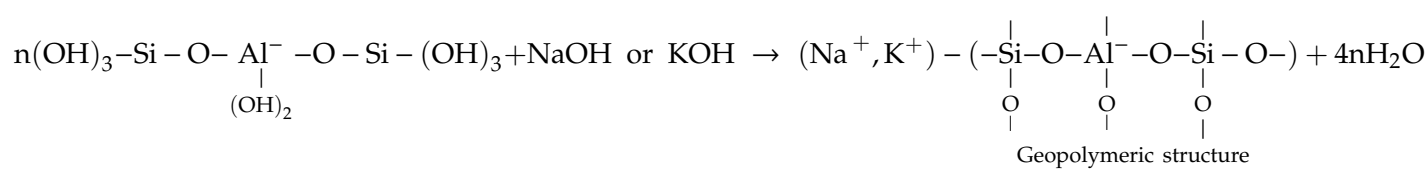

The ratio of residual compressive strength to original compressive strength is illustrated in Figure 8. The ratios for OPC-0, OPC- 5 and OPC- 10 are about $167 \%, 103 \%$, and $114 \%$ respectively at $200{ }^{\circ} \mathrm{C}$ and the values are about $60 \%, 29 \%$ and $48 \%$ respectively at $800{ }^{\circ} \mathrm{C}$. These residual strengths are higher than those usually found for cement-based concrete [38] and heat-cured fly ash-based geopolymer concrete [18].

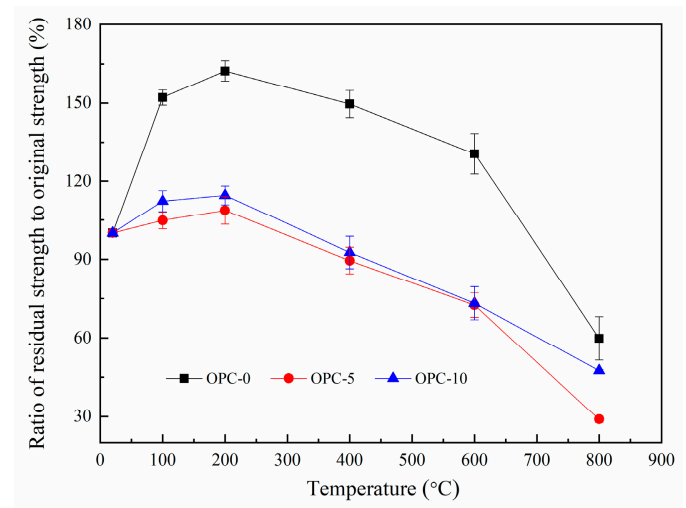

Figure 8. Ratio of residual compressive strength to original compressive strength.

\subsection{Microstructure Investigation}

SEM analysis was used to evaluate the characteristic of FAGC microstructure at different temperatures and the results are illustrated in Figures 9-11. 


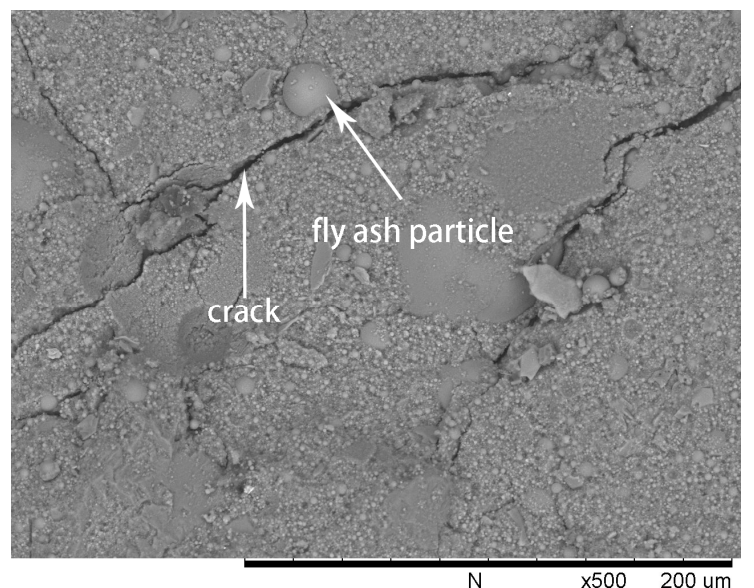

(a) $\mathrm{OPC}-0-20{ }^{\circ} \mathrm{C}$

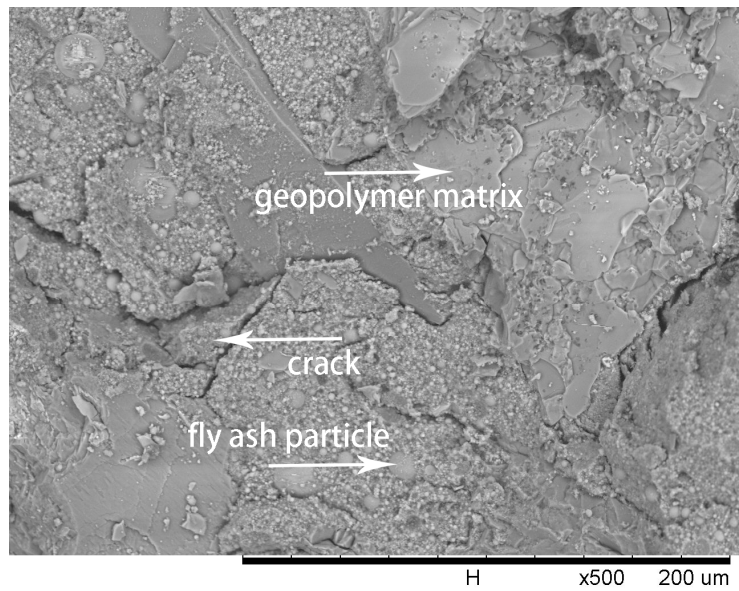

(c) $\mathrm{OPC}-0-200{ }^{\circ} \mathrm{C}$

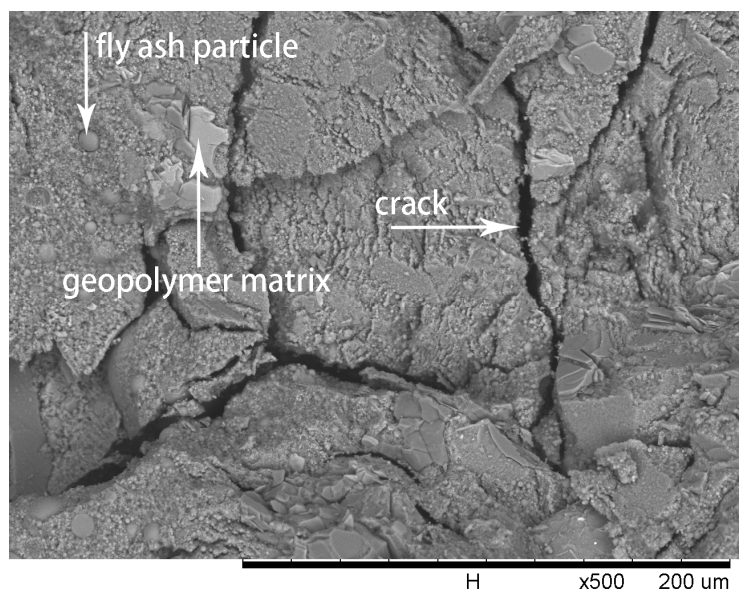

(e) $\mathrm{OPC}-0-600{ }^{\circ} \mathrm{C}$

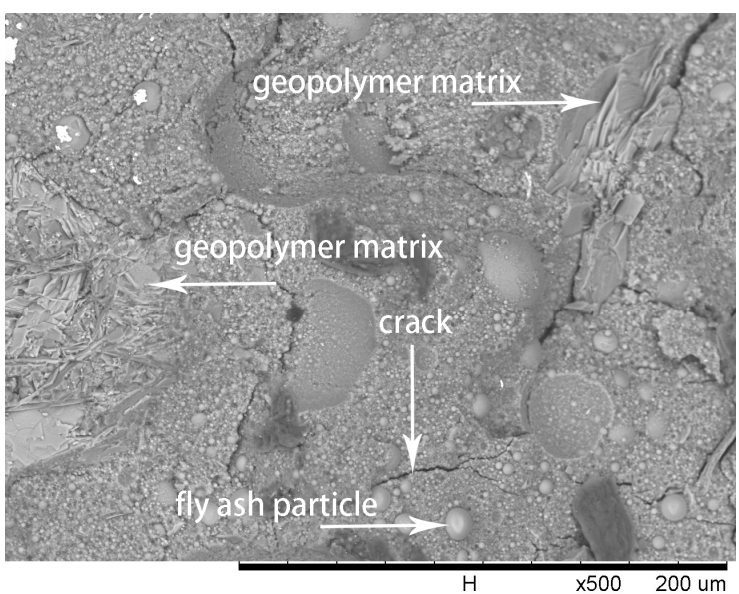

(b) $\mathrm{OPC}-0-100{ }^{\circ} \mathrm{C}$

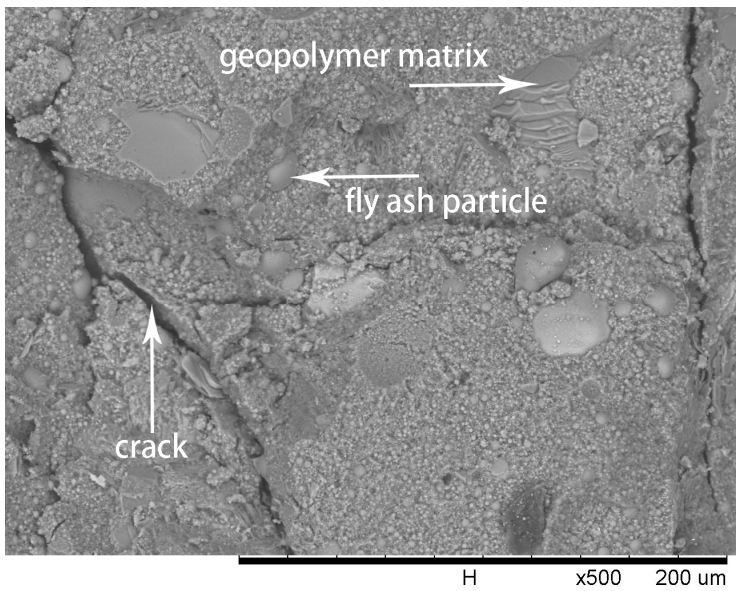

(d) $\mathrm{OPC}-0-400^{\circ} \mathrm{C}$

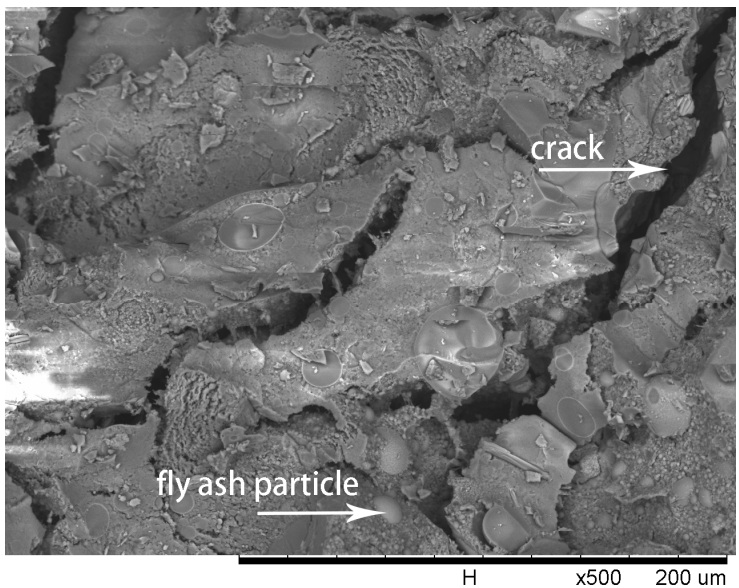

(f) OPC- $0-800{ }^{\circ} \mathrm{C}$

Figure 9. SEM micrographs of OPC-0 series at different temperatures. 


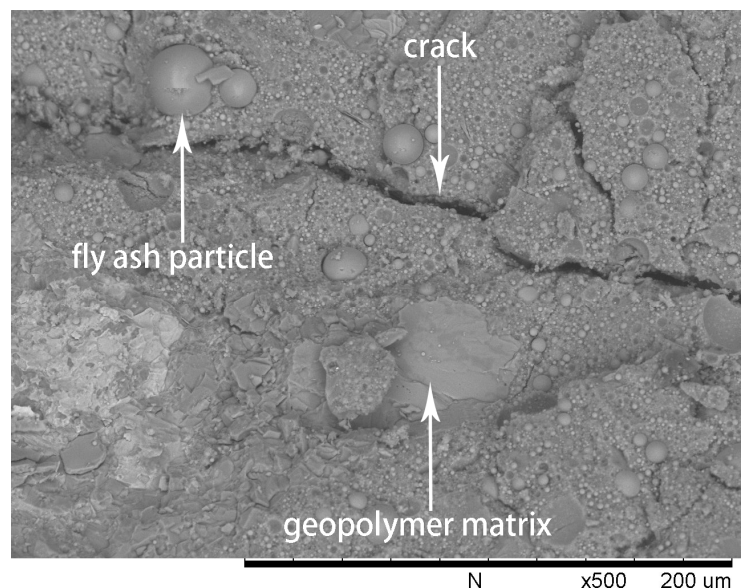

(a) OPC $-5-20{ }^{\circ} \mathrm{C}$

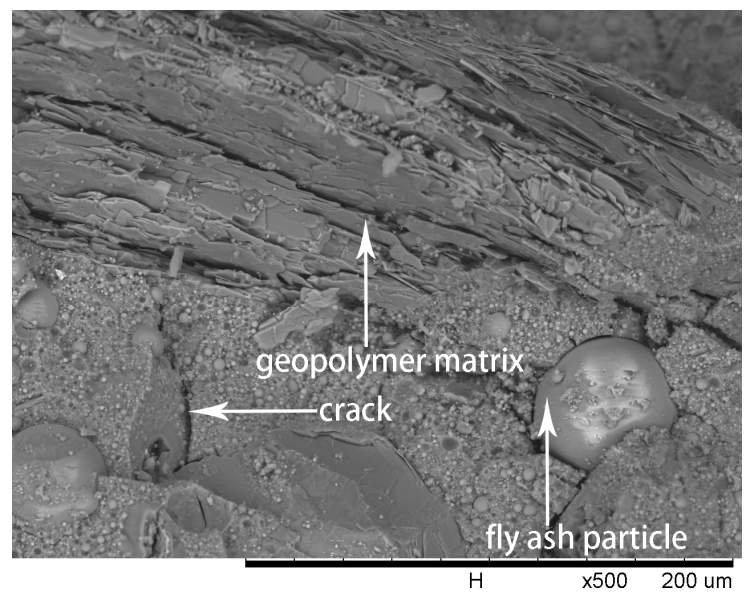

(c) $\mathrm{OPC}-5-200{ }^{\circ} \mathrm{C}$

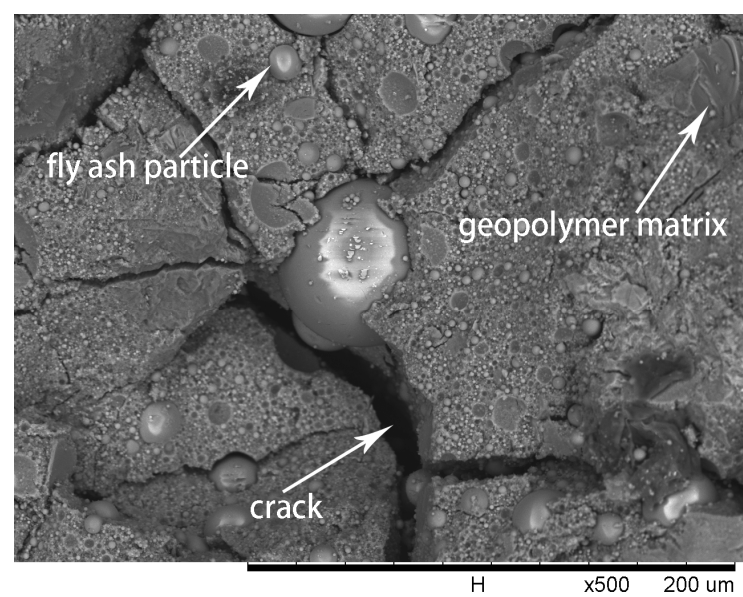

(e) $\mathrm{OPC}-5-600{ }^{\circ} \mathrm{C}$

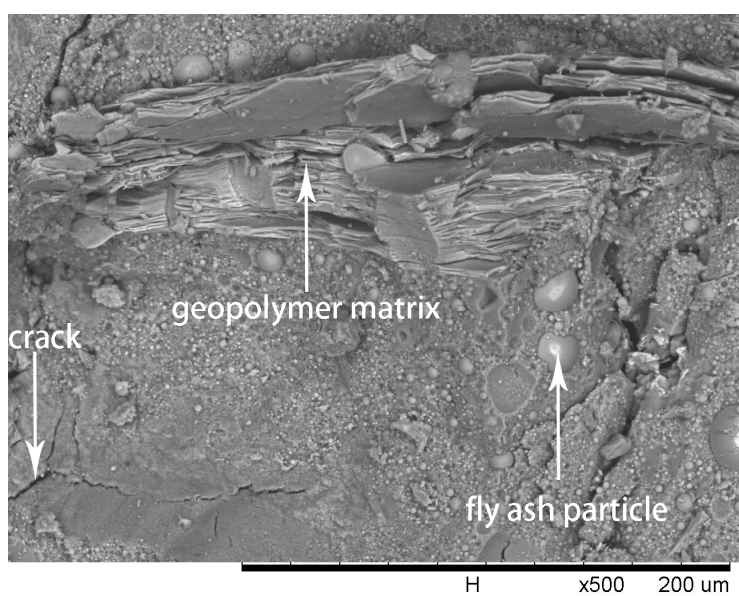

(b) $\mathrm{OPC}-5-100{ }^{\circ} \mathrm{C}$

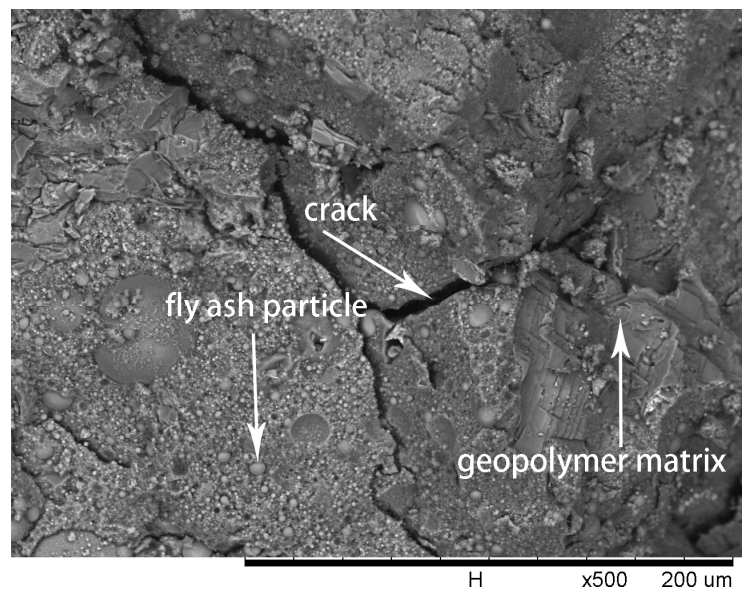

(d) $\mathrm{OPC}-5-400{ }^{\circ} \mathrm{C}$

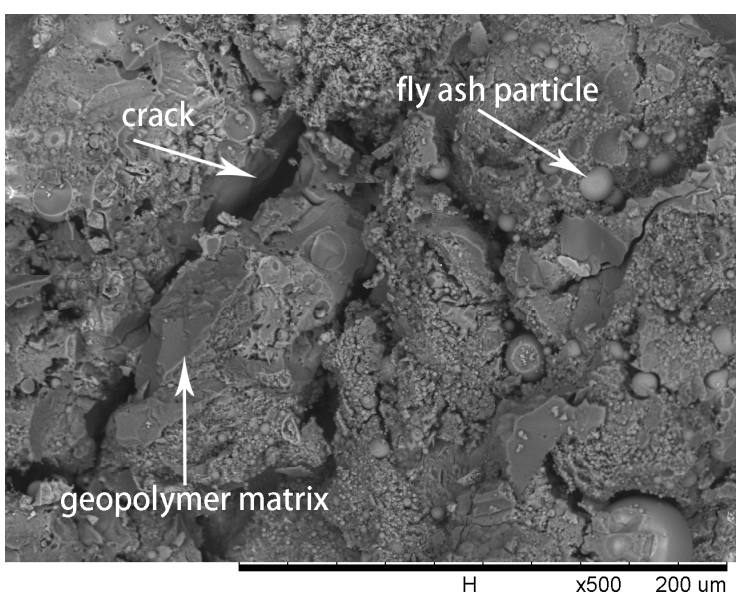

(f) $\mathrm{OPC}-5-800{ }^{\circ} \mathrm{C}$

Figure 10. SEM micrographs of OPC-5 series at different temperatures. 


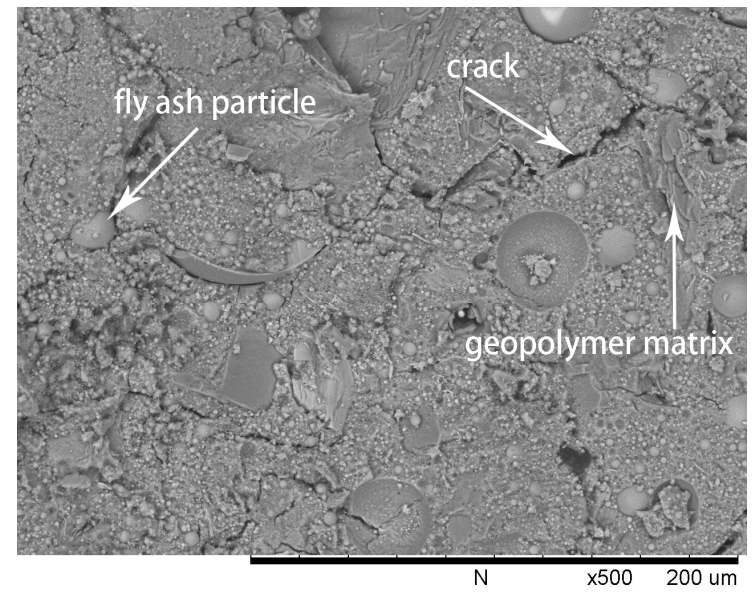

(a) $\mathrm{OPC}-10-20^{\circ} \mathrm{C}$

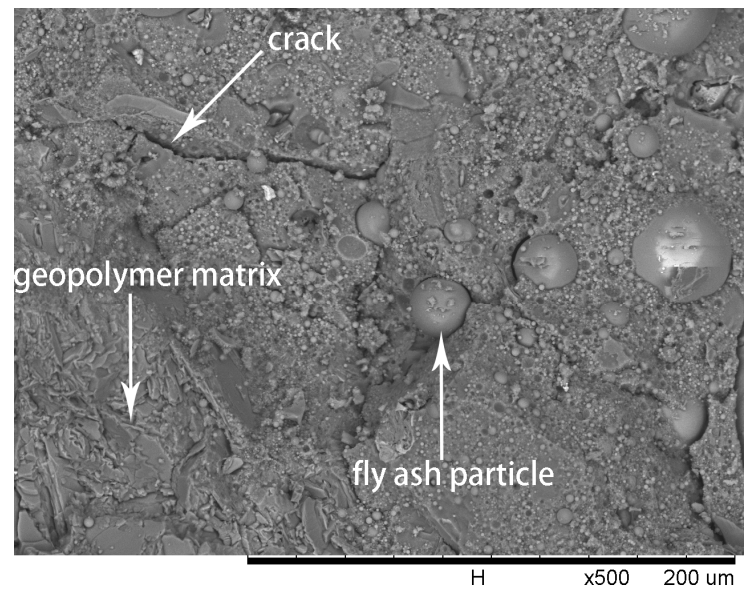

(c) $\mathrm{OPC}-10-200^{\circ} \mathrm{C}$

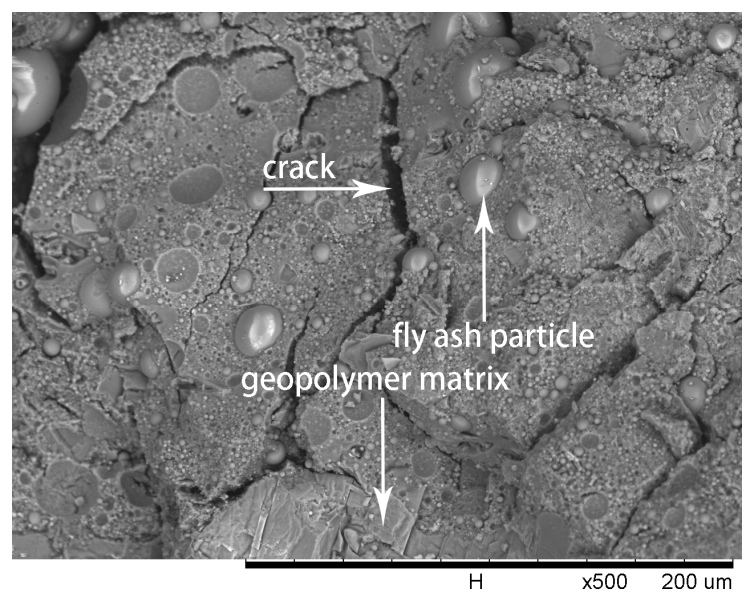

(e) OPC- $10-600{ }^{\circ} \mathrm{C}$

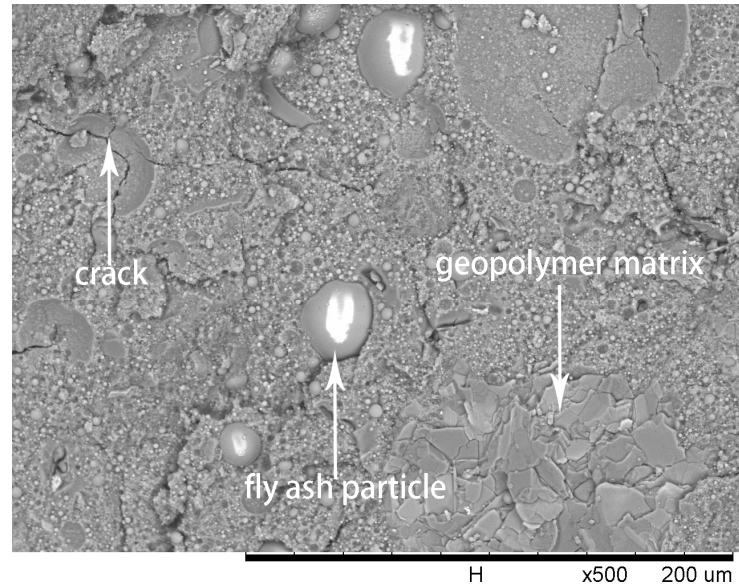

(b) OPC-10-100 ${ }^{\circ} \mathrm{C}$

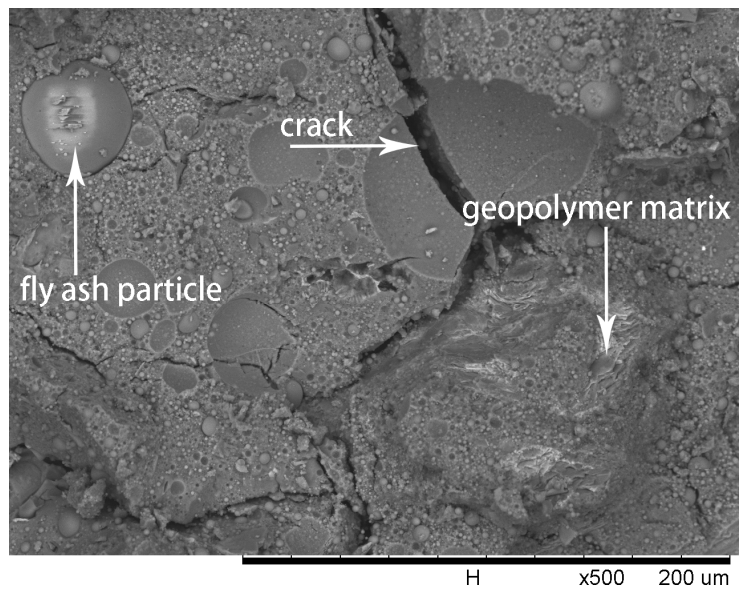

(d) OPC-10-400 ${ }^{\circ} \mathrm{C}$

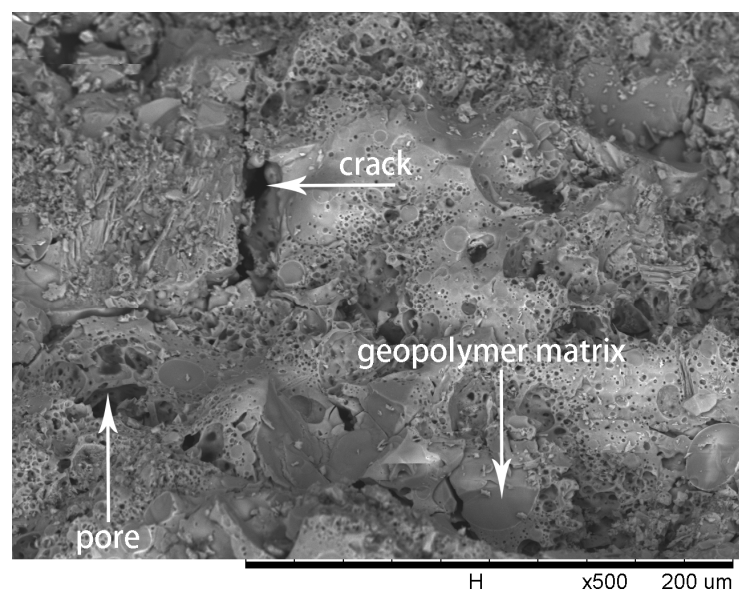

(f) $\mathrm{OPC}-10-800{ }^{\circ} \mathrm{C}$

Figure 11. SEM micrographs of OPC-10 series at different temperatures.

Comparing with Figure 2a, the spherical particles in Figure 9 are believed to be unreacted fly ash particles. The residual fly ash particles would provide essential materials for the potential secondary geopolymerization. The cracks of geopolymer matrix after exposures to $100{ }^{\circ} \mathrm{C}$ and $200{ }^{\circ} \mathrm{C}$, as shown in Figure $9 \mathrm{~b}, \mathrm{c}$, are less wide than those of the matrix at $20^{\circ} \mathrm{C}$, as shown in Figure 9 a. The reduction of crack width in the matrix after the exposures of $100^{\circ} \mathrm{C}$ and $200^{\circ} \mathrm{C}$ is attributed to the increase of 
reaction products by the secondary geopolymerization that occurred under exposure temperatures. Therefore, the growth in compressive strength of FAGCs up to $200{ }^{\circ} \mathrm{C}$ is attributed to secondary geopolymerization, which improved the microstructure of concrete. The quantity of cracks increased and the width of cracks widened in the temperature range of $400{ }^{\circ} \mathrm{C}$ to $800^{\circ} \mathrm{C}$ that deteriorated the internal structure of FAGC and eventually reduced the compressive strength. Exposure to $800{ }^{\circ} \mathrm{C}$ resulted in the highest deterioration of microstructure as illustrated in Figure 9f. Thus, the FAGCs had the lowest residual compressive strength (Figure 7) after being subjected to $800^{\circ} \mathrm{C}$. The difference in thermal expansions of geopolymer matrix and aggregates also contributed to the deterioration of microstructure and expansion of cracks. Additionally, the vapor pressure caused by the vaporization of free water as well as chemically combined water resulted in further development of cracks. The swelling of residual silicate were also responsible for the degradations of microstructure and compressive strength deterioration [16].

The SEM images of OPC- 5 and OPC-10 before and after exposure to elevated temperatures are presented in Figures 10 and 11. It is observed from Figures 10a and 11a that use of cement could improve the microstructure, resulting in higher initial compressive strength of FAGCs. Unreacted fly ash particles were also observed in FAGCs containing cement, therefore, the strength enhancement in OPC-5 and OPC- 10 series up to $200^{\circ} \mathrm{C}$ was also due to secondary geopolymerization. Being consistent with the microstructure of OPC- 0 samples, the microstructures of OPC -5 and OPC-10 concrete samples also suffered from severe deterioration in microstructure within the temperature range of $400{ }^{\circ} \mathrm{C}$ to $800{ }^{\circ} \mathrm{C}$. It was observed that OPC- 5 and OPC-10 samples suffered more severe microstructure deterioration than OPC-0 samples. Therefore, the residual compressive strength of FAGCs containing cement was lower than the samples of OPC- 0 series overall during the temperature range of $400{ }^{\circ} \mathrm{C}$ to $800{ }^{\circ} \mathrm{C}$. It is important to understand why cement would have harmful effect on the elevated temperature resistance of FAGC after exposure to $400{ }^{\circ} \mathrm{C}$. Firstly, Abdulkareem et al. [16] showed that the elevated temperature resistance of geopolymer concrete could be significantly weakened by the densification and swelling process of residual silicate phases within the temperature range of $600-800{ }^{\circ} \mathrm{C}$. Cement could help FAGC to produce a relatively highly dense microstructure at ambient temperature, which could be observed from Figures 9a, 10a and 11a. Therefore, OPC-5 and OPC-10 would suffer more microstructural deterioration according to the observation of Abdulkareem et al. [16]. Secondly, the introduction of cement tended to increase the $\mathrm{Ca} / \mathrm{Si}$ ratio and quantities of $\mathrm{C}-\mathrm{S}-\mathrm{H}$ gel due to the high $\mathrm{CaO}$ content in cement. The promotion in the $\mathrm{Ca} / \mathrm{Si}$ ratio value and the amounts of $\mathrm{C}-\mathrm{S}-\mathrm{H}$ weakened the elevated temperature resistance of FAGC [39]. The statement was also supported by the results of OPC-10 up to $600^{\circ} \mathrm{C}$.

No visible particles are observed in Figure $11 \mathrm{f}$ and OPC-10 samples experienced larger mass loss between 600 and $800{ }^{\circ} \mathrm{C}$ (Figures 5 and 6), which implied that the unreacted fly ash particles have fused and melted within this temperature range. Rickard et al. [40] argued that the increase of strength at temperature higher than $800{ }^{\circ} \mathrm{C}$ was ascribed to the sintering and melting. However, the sintering and melting seemed to have occurred at temperature higher than $600{ }^{\circ} \mathrm{C}$ in OPC-10 series (Figure 11f). Therefore, OPC-10 specimens performed higher residual compressive strength than OPC-0 specimens at $800{ }^{\circ} \mathrm{C}$ (Figure 7). It can be observed from Tables 1 and 2 that the inclusion of cement could increase the $\mathrm{Ca} / \mathrm{Si}$ ratio in FAGC specimens, indicating the increasing $\mathrm{Ca} / \mathrm{Si}$ ratio might facilitate the sintering and melting appeared at lower temperatures.

\section{Conclusions}

This paper presented behavior of ambient-cured low-calcium FAGCs containing different, ordinary Portland cement dosages after exposure to elevated temperatures. The following conclusions could be derived from the experimental results:

1. The mass loss occurred at temperatures up to $200{ }^{\circ} \mathrm{C}$ accounted for more than $50 \%$ of the entire mass loss, which mainly resulted from the evaporation of free water and chemically bound water. 
The mass loss ratio increased with the cement content, which was caused by the continuous dehydroxylation of C-S-H gels as well as the disintegration of $\mathrm{Ca}(\mathrm{OH})_{2}$ at elevated temperatures.

2. All the FAGCs performed higher compressive strength than their original compressive strength up to $200^{\circ} \mathrm{C}$, which was due to the secondary geopolymerization resulting from unreacted fly ash and alkaline solution. FAGCs without cement experienced higher strength enhancement than those containing cement. More impressive, FAGCs without cement retained higher compressive strength than its original compressive strength until $600^{\circ} \mathrm{C}$.

3. The SEM images demonstrated that the compressive strength enhancement resulted from secondary geopolymerization that produced further geopolymer gels and improved the concrete microstructure. SEM, TGA and DTG results revealed that the compressive strength loss occurred at temperatures higher than $200{ }^{\circ} \mathrm{C}$ was mainly caused by the microstructure deterioration and the continuous dehydroxylation of N-A-S-H gel.

4. Compressive strength of FAGCs increased with the cement dosages up to $200{ }^{\circ} \mathrm{C}$ because of the existence of C-S-H gels and filler effect of cement. According to the SEM results, the fact that cement was beneficial for improving microstructure of FAGCs caused the compressive strength enhancement.

5. The inclusion of cement increased the $\mathrm{Ca} / \mathrm{Si}$ ratio, which resulted in an increase in the quantity of calcium compounds with strong thermal expansion properties. Therefore, FAGCs containing cement suffered from more severe strength loss and microstructure deterioration than FAGCs without cement at temperatures higher than $200^{\circ} \mathrm{C}$.

Author Contributions: Data curation, H.Z.; Funding acquisition, X.S. and Q.W.; Investigation, H.Z., L.L. and T.L.; Methodology, H.Z., X.S. and Q.W.; Visualization, H.Z. and P.K.S.; Writing-original draft, H.Z.; Writing-review \& editing, P.K.S., X.S., G.C. and Q.W. All authors contributed equally to this paper. All authors read and approved the final manuscript.

Funding: This research was funded by the Program for Changjiang Scholars and Innovative Research Team (IRT14R37), the National Natural Science Foundation of China (51208325) and the Science \& Technology Support Program of Sichuan Province (No. 2015GZ0245 and No. 2015JPT0001).

Acknowledgments: The first author is supported by the China Scholarship Council (CSC), which is sincerely appreciated.

Conflicts of Interest: The authors declare no conflicts of interest.

\section{References}

1. Davidovits, J. Geopolymers and geopolymeric materials. J. Ther. Anal. 1989, 35, 429-441. [CrossRef]

2. Duxson, P.; Fernández-Jiménez, A.; Provis, J.L.; Lukey, G.C.; Palomo, A.; van Deventer, J.S.J. Geopolymer technology: the current state of the art. J. Mater. Sci. 2007, 42, 2917-2933. [CrossRef]

3. Nath, P.; Sarker, P. Fly ash based geopolymer concrete: A review. New Dev. Struct. Eng. Constr. 2013, 1091-1096. [CrossRef]

4. Bucher, R.; Diederich, P.; Escadeillas, G.; Cyr, M. Service life of metakaolin-based concrete exposed to carbonation: Comparison with blended cement containing fly ash, blast furnace slag and limestone filler. Cem. Concr. Res. 2017, 99, 18-29. [CrossRef]

5. Ding, Y.; Bai, Y.L. Fracture Properties and Softening Curves of Steel Fiber-Reinforced Slag-Based Geopolymer Mortar and Concrete. Materials. 2018, 11, 1445. [CrossRef] [PubMed]

6. Diaz-Loya, E.I.; Allouche, E.N.; Vaidya, S. Mechanical properties of fly-ash-based geopolymer concrete. ACI Mater. J. 2011, 108, 300.

7. Adam, A. Strength and durability properties of alkali activated slag and fly ash-based geopolymer concrete. Ph.D. Thesis, RMIT University, Melbourne, Australia, 2009.

8. Shi, X.S.; Collins, F.G.; Zhao, X.L.; Wang, Q.Y. Mechanical properties and microstructure analysis of fly ash geopolymeric recycled concrete. J. Hazard. Mater. 2012, 237-238, 20-29. [CrossRef] [PubMed]

9. Nath, P.; Sarker, P.K. Effect of GGBFS on setting, workability and early strength properties of fly ash geopolymer concrete cured in ambient condition. Constr. Building Mater. 2014, 66, 163-171. [CrossRef] 
10. Aslani, F.; Asif, Z. Properties of ambient-cured normal and heavyweight geopolymer concrete exposed to high temperatures. Materials 2019, 12, 740. [CrossRef]

11. Xie, T.; Ozbakkaloglu, T. Behavior of low-calcium fly and bottom ash-based geopolymer concrete cured at ambient temperature. Ceram. Int. 2015, 41, 5945-5958. [CrossRef]

12. Nath, P.; Sarker, P.K. Use of OPC to improve setting and early strength properties of low calcium fly ash geopolymer concrete cured at room temperature. Cem. Concr. Compos. 2015, 55, 205-214. [CrossRef]

13. Hongen, Z.; Feng, J.; Qingyuan, W.; Ling, T.; Xiaoshuang, S. Influence of Cement on Properties of Fly-Ash-Based Concrete. ACI Mater. J. 2017, 114, 745-753. [CrossRef]

14. Zhang, H.; Shi, X.; Wang, Q. Effect of Curing Condition on Compressive Strength of Fly Ash Geopolymer Concrete. ACI Mater. J. 2018, 115, 191-196. [CrossRef]

15. Sarker, P.K.; Kelly, S.; Yao, Z. Effect of fire exposure on cracking, spalling and residual strength of fly ash geopolymer concrete. Mater. Des. 2014, 63, 584-592. [CrossRef]

16. Abdulkareem, O.A.; Al Bakri, A.M.M.; Kamarudin, H.; Khairul Nizar, I.; Saif, A.A. Effects of elevated temperatures on the thermal behavior and mechanical performance of fly ash geopolymer paste, mortar and lightweight concrete. Constr. Building. Mater. 2014, 50, 377-387. [CrossRef]

17. Shaikh, F.U. Effect of cooling on the residual mechanical properties and cracking of plain and fibrous geopolymer concretes at elevated temperatures. Struct. Concr. 2019, 40. [CrossRef]

18. Shaikh, F.U.; Vimonsatit, V. Compressive strength of fly-ash-based geopolymer concrete at elevated temperatures. Fire. Mater. 2015, 39, 174-188. [CrossRef]

19. ASTM, C. Standard specification for coal fly ash and raw or calcined natural pozzolan for use in concrete. ASTM Int. 2012, 04.02. [CrossRef]

20. GB 175-2007 Common Portland Cement; Standards Press of China: Beijing, China, 2007.

21. Ministry of Transport of the People's Republic of China/Chinese Planning. GB/T 50081-2002 Standard for Test Method of Mechanical Properties on Ordinary Concrete; Ministry of Transport of the People's Republic of China/Chinese Planning: Beijing, China, 2003.

22. Pan, Z.; Sanjayan, J.G.; Collins, F. Effect of transient creep on compressive strength of geopolymer concrete for elevated temperature exposure. Cem. Concr. Res. 2014, 56, 182-189. [CrossRef]

23. Rashad, A.M. Potential use of phosphogypsum in alkali-activated fly ash under the effects of elevated temperatures and thermal shock cycles. J. Cleaner. Prod. 2015, 87, 717-725. [CrossRef]

24. Rashad, A.M.; Zeedan, S.R. The effect of activator concentration on the residual strength of alkali-activated fly ash pastes subjected to thermal load. Constr. Build. Mater. 2011, 25, 3098-3107. [CrossRef]

25. Fares, H.; Remond, S.; Noumowe, A.; Cousture, A. High temperature behaviour of self-consolidating concrete: microstructure and physicochemical properties. Cem. Concr. Res. 2010, 40, 488-496. [CrossRef]

26. Laneyrie, C.; Beaucour, A.L.; Green, M.F.; Hebert, R.L.; Ledesertet, B.; Noumowe, A. Influence of recycled coarse aggregates on normal and high performance concrete subjected to elevated temperatures. Constr. Building. Mater. 2016, 111, 368-378. [CrossRef]

27. Palomo, A.; Fernández-Jiménez, A.; Kovalchuk, G.; Ordoñez, L.M.; Naranjo, M.C. OPC-fly ash cementitious systems: study of gel binders produced during alkaline hydration. J. Mater. Sci. 2007, 42, 2958-2966. [CrossRef]

28. Ranjbar, N.; Mehrali, M.; Alengaram, U.J.; Metselaar, H.S.C.; Zamin Jumaat, M. Compressive strength and microstructural analysis of fly ash/palm oil fuel ash based geopolymer mortar under elevated temperatures. Constr. Building. Mater. 2014, 65, 114-121. [CrossRef]

29. Khoury, G.A. Compressive strength of concrete at high temperatures: a reassessment. Mag. Concr. Res. 1992, 44, 291-309. [CrossRef]

30. Liu, X.; Ye, G.; De Schutter, G.; Yuan, Y.; Taerwe, L. On the mechanism of polypropylene fibres in preventing fire spalling in self-compacting and high-performance cement paste. Cem. Concr. Res. 2008, 38, 487-499. [CrossRef]

31. Liu, X. Microstructural Investigation of Self-Compacting Concrete and High-Performance Concrete during Hydration and after Exposure to High Temperatures. Ph.D. Thesis, Université de Ghent, Belgique, March 2006.

32. Andiç-Çakır, Ö.; Hızal, S. Influence of elevated temperatures on the mechanical properties and microstructure of self consolidating lightweight aggregate concrete. Constr. Build. Mater. 2012, 34, 575-583. [CrossRef] 
33. Nadeem, A.; Memon, S.A.; Lo, T.Y. Mechanical performance, durability, qualitative and quantitative analysis of microstructure of fly ash and Metakaolin mortar at elevated temperatures. Constr. Build. Mater. 2013, 38, 338-347. [CrossRef]

34. Rahier, H.; Van Mele, B.; Wastiels, J. Low-temperature synthesized aluminosilicate glasses. Part II Rheological transformations during low-temperature cure and high-temperature properties of a model compound. J. Mater. Sci. 1996, 31, 80-85.

35. Türkmen, İ.; Karakoç, M.B.; Kantarcı, F.; Maraş, M.M.; Demirboğa, R. Fire resistance of geopolymer concrete produced from Elazığ ferrochrome slag. Fire. Mater. 2016, 40, 836-847. [CrossRef]

36. Zuhua, Z.; Xiao, Y.; Huajun, Z.; Yue, C. Role of water in the synthesis of calcined kaolin-based geopolymer. Appl. Clay Sci. 2009, 43, 218-223. [CrossRef]

37. Van Jaarsveld, J.; Van Deventer, J.; Lorenzen, L. The potential use of geopolymeric materials to immobilise toxic metals: Part I. Theory and applications. Miner. Eng. 1997, 10, 659-669. [CrossRef]

38. Chan, Y.; Peng, G.; Anson, M. Residual strength and pore structure of high-strength concrete and normal strength concrete after exposure to high temperatures. Cem. Concr. Compos. 1999, 21, 23-27. [CrossRef]

39. Hussin, M.W.; Bhutta, M.A.R.; Azreen, M.; Ramadhansyah, P.J.; Mirza, J. Performance of blended ash geopolymer concrete at elevated temperatures. Mater. Struct. 2015, 48, 709-720. [CrossRef]

40. Rickard, W.D.; Kealley, C.S.; Van Riessen, A. Thermally induced microstructural changes in fly ash geopolymers: Experimental results and proposed model. J. Am. Ceram. Soc. 2015, 98, 929-939. [CrossRef]

(C) 2019 by the authors. Licensee MDPI, Basel, Switzerland. This article is an open access article distributed under the terms and conditions of the Creative Commons Attribution (CC BY) license (http://creativecommons.org/licenses/by/4.0/). 